\title{
Ponderosa Pine Seed Source Test in Nebraska in the Central Great Plains of the United States
}

\author{
Wayne A. Geyer ${ }^{1 *}$, Keith D. Lynch ${ }^{1}$, Peter Schaefer ${ }^{2}$, William R. Lovette ${ }^{3}$ \\ ${ }^{1}$ Division of Forestry, Kansas State University, Manhattan, USA \\ ${ }^{2}$ Department of Plant Science, South Dakota University, Vermillion, USA \\ ${ }^{3}$ Nebraska Forest Service, Lincoln NE 68583 Nebraska Forest Service, Lincoln, USA \\ Email: *wgeyer@ksu.edu
}

Received March $15^{\text {th }}$, 2013; revised May $9^{\text {th }}$, 2013; accepted May 24 ${ }^{\text {th }}, 2013$

\begin{abstract}
Copyright $\odot 2013$ Wayne A. Geyer et al. This is an open access article distributed under the Creative Commons Attribution License, which permits unrestricted use, distribution, and reproduction in any medium, provided the original work is properly cited.
\end{abstract}

\begin{abstract}
Ponderosa pine (Pinus ponderosa Laws) has been planted widely in the Great Plains for wind breaks. A 1968 study recommended using material from south-central South Dakota and north-central Nebraska. A second test to further delineate seed sources (families) from numerous collection sites in this region was established in 1986. This paper reports results for survival, height, diameter, and $\mathrm{D}^{2} \mathrm{H}$ (diameter squared $\mathrm{X}$ height) measurements at 15 years. Results identify a wide range of suitable families within the region. A majority of the tested sources performed well, thus verifying the original recommendations.
\end{abstract}

Keywords: Pinus ponderosa; Provenance; Seed Source; Family; Tree Selection; Growth Characteristics

\section{Introduction}

Ponderosa pine (Pinus ponderosa Laws) is an important component of the windbreak agroforestry system in the Great Plains. Its drought tolerance, dense crown form, and tall growth habit make ponderosa pine excellent for windbreaks, sight barriers, and ornamental plantings (Flint, 1983). Ponderosa pine is one of the few tall trees that grow in the region. Because of its evergreen nature, it provides year-round protection to fields and farmsteads (Schaefer \& Baer, 1985). The natural range of ponderosa pine extends from British Columbia, Canada, southward into northern Mexico, and from California eastward into the Great Plains, excluding for Kansas (Crichfield \& Little, 1966). Although ponderosa pine has been widely planted in the plains region, it has performed inconsistently.

Western pine tip moth (Rhyacioniabushnelli) has caused widespread damage in the plains (Kopp et al., 1987), but outstanding performance of individual trees in the plains plantations suggests that proper selection could improve tree quality.

Early studies determined that trees grown from seed collected from the northeastern range of ponderosa pine performed best in most of the provenance test plantations (Deneke \& Read, 1975; Baer \& Collins, 1979; Read, 1983; Schaefer \& Baer, 1985, 1992; Van Haverbeke, 1986). Six years data from a Kansas plantation showed that early growth appeared to be clinally related to elevation of seed provenances (Deneke \& Read, 1975). Plains nurseries have focused much of their ponderosa pine production on seed collections near Ainsworth and Valentine, Nebraska, and Rosebud, South Dakota.

Trees from Jordan, Montana, also performed well in more than half of the early plantations (Read, 1983).

In 1986, the GP-13 Technical Committee of the Great Plains

*Corresponding author.
Agricultural Council initiated a second cooperative ponderosa pine study in cooperation with the North Central and Rocky Mountain Forest Experiment Stations. The intent of this study was to further sample recommended provenances identified in the 1968 study. Collection sites are shown in Figure 1. Nine progeny tests were established in Saskatchewan (Canada), Montana, North Dakota, South Dakota, Nebraska, Kansas, Oklahoma, Texas, and Minnesota. This paper reports data from the Nebraska test. A previous report (Geyer \& Schaefer, 2011) indicated that 1968 recommendations were valid for Kansas and South Dakota.

\section{Materials and Methods}

The tree plantation discussed in this report here used seedlings representing 96 open-pollinated families (Figure 1, Table 1) that were planted in an individual tree factorial planting design with 8 replications and $3.7 \times 3.7 \mathrm{~m}(12 \times 12 \mathrm{ft})$ plots. Each replication was included 5 trees in single-tree, noncomtiguous plots. Two border rows surrounded the plantation. A total of 3840 trees were planted. Weeds were controlled by cultivation for the first 3 years. The plantation was near Republican City, Nebraska, on an alluvial site.

Superior height growth potential can be accurately identified at an early age (i.e., 5 to 15 years); (Lambeth, 1980; Read, 1983; Van Haverbeke, 1986; Schaefer \& Baer, 1992). For analysis, we applied the GLM procedure of SAS (SAS Institute, 2003) for height, trunk diameter, and $\mathrm{D}^{2} \mathrm{H}$ (a measure of trunk volume); Duncan's multiple range test for mean separation; and chi-square for survival, stem crook, sweep, and number of terminal buds. Correlations were determined among height, diameter, $\mathrm{D}^{2} \mathrm{H}$, and latitude and longitude of each major geographic (provenance) location. The 13 major geographic zones (provenances) and 96 seed sources (families) were compared. 
Table 1.

Collection zones (provenances) of ponderosa pine seed sources.

\begin{tabular}{cccccccc}
\hline $\begin{array}{c}\text { Geographic } \\
\text { origin (\#) }\end{array}$ & $\begin{array}{c}\text { Tree additions } \\
\text { (families) }(\#)\end{array}$ & $\begin{array}{c}\text { Local area } \\
\text { (town/state) }\end{array}$ & $\begin{array}{c}\text { Annual } \\
\text { precipitation }((\mathrm{mm})(\mathrm{in}))\end{array}$ & $\begin{array}{c}\text { Annual mean } \\
\text { temp. }{ }^{\circ} \mathrm{C}\left({ }^{\circ} \mathrm{F}\right)\end{array}$ & $\begin{array}{c}\text { Elevation } \\
\mathrm{m}(\mathrm{ft})\end{array}$ & $\begin{array}{c}\text { Latitude } \\
\left({ }^{\circ} \mathrm{N}\right)\end{array}$ & $\begin{array}{c}\text { Longitude } \\
\left({ }^{\circ} \mathrm{W}\right)\end{array}$ \\
\hline 720 & $02-11$ & Ainsworth NE & $579(22.8)$ & $8.6(47.6)$ & $780(2560)$ & 42.59 & 100.00 \\
721 & $01-11$ & Valentine NE & $495(19.5)$ & $8.4(47.2)$ & $800(2625)$ & 42.88 & 100.55 \\
757 & $01-40$ & Rosebud SD & $955(37.6)$ & $8.5(47.7)$ & $850(2789)$ & 43.25 & 100.82 \\
990 & $01-10$ & Springview NE & $573(22.7)$ & $8.3(47.0)$ & $740(2428)$ & 42.82 & 99.75 \\
991 & $01-05$ & Kilgore NE & $516(20.3)$ & $8.3(47.0)$ & $800(2625)$ & 42.94 & 100.97 \\
992 & $01-04$ & Drinkwater NE & $495(19.5)$ & $8.3(47.0)$ & $859(2800)$ & 42.47 & 101.07 \\
993 & $01-07$ & Nenzel NE & $526(20.3)$ & $9.0(48.3)$ & $950(3117)$ & 42.93 & 101.11 \\
994 & $01-05$ & Bassett NE & $635(25.0)$ & $9.0(48.3)$ & $710(2329)$ & 42.60 & 99.54 \\
995 & $01-06$ & Snake River NE & $495(19.5)$ & $8.3(47.00$ & $866(2840)$ & 42.71 & 100.97 \\
996 & $01-14$ & Sparks NE & $495(19.5)$ & $8.3(47.0)$ & $800(2625)$ & 42.94 & 100.24 \\
\hline
\end{tabular}

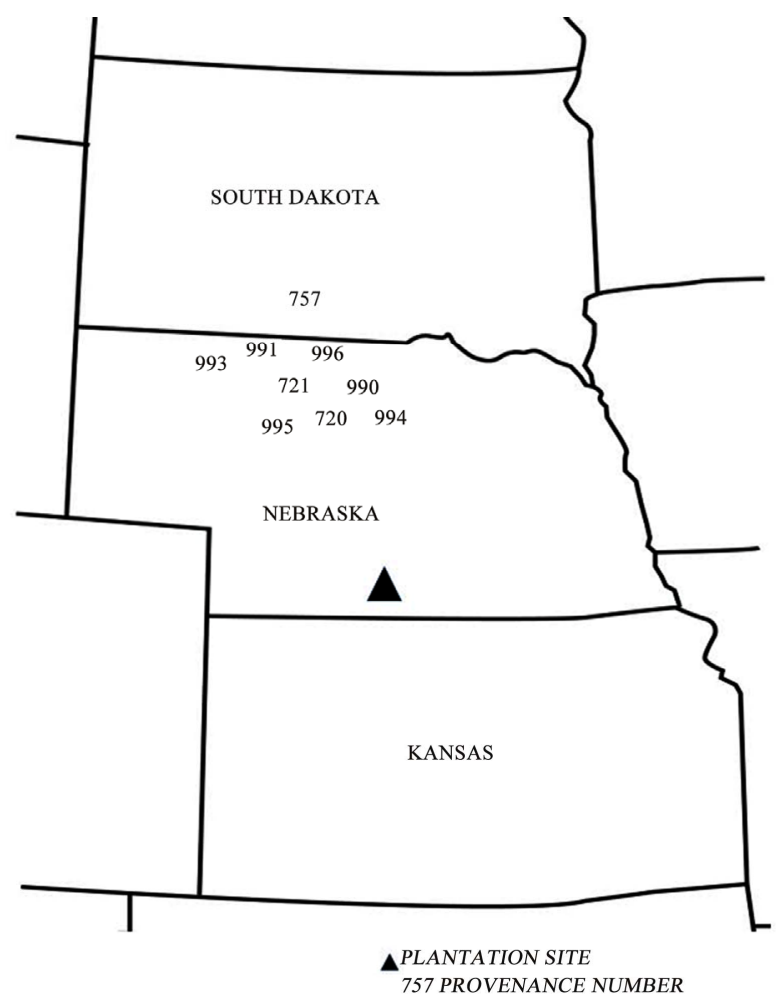

Figure 1.

Collection zones (provenances) of ponderosa pine seed sources.

Most of the sources were from north central Nebraska and southern South Dakota. An operational thinning was conducted at 15 years to remove insect-infested trees and trees of poor stature before an inventory.

\section{Results and Discussion}

Few differences existed in the size of most families because all trees were measured after thinning. Total family height varied by location. Mean height of all families was $6.8 \mathrm{~m}(22.4 \mathrm{ft})$ with a range from 5.9 to $7.8 \mathrm{~m}$ (19.0 to $25.5 \mathrm{ft})$. The top 10 families (Table 2) differed by $0.4 \mathrm{~m}(1.4 \mathrm{ft})$; and were significantly taller than only the shortest three families. The poorest 10 families ranged from 5.9 to $6.2 \mathrm{~m}$ (19.0 to $20.5 \mathrm{ft}$ ) and were significantly different (1\% level) from only the tallest two families. The top 85 families did not differ significantly from each other, and the shortest family was $6.4 \mathrm{~m}$ (21.0 ft).

Mean diameter was $17.8 \mathrm{~cm}$ (7.0 in) with a range of 14.2 to $23.1 \mathrm{~cm}$ (5.6 to $9.1 \mathrm{in})$. The best 10 families differed by $3.6 \mathrm{~cm}$ (1.4 in) and the poorest 10 families differed by $3.0 \mathrm{~cm}$ (1.2 in). As with height, only families at either end of the ranking were significantly different. The top two families had significantly larger diameters than the bottom 84, whereas the bottom three families had significantly smaller diameters then the top 17. Although trees with the largest diameter tended to be taller ( $r=$ $0.16179 \%, 1 \%$ level), only family 72,111 ranked in top 10 for both diameter and height. Survival was not good for the largest 10 families. Many families (49) had less than 20\% survival. Survival of trees with the largest diameter, ranged from 3 to $20 \%$.

Trunk volume was significantly different (1\% level) among families (Table 1). The mean $\mathrm{D}^{2} \mathrm{H}$ was 1126 units with a range from 651 to 1889 . The largest 38 were not significantly different. The top six sources were significantly larger than the bottom 7.

Mean survival was surprisingly low, ranging from 3.3 to $56.7 \%$ with a mean of $21.3 \%$. Four of the top 7 families were from Spring view, Nebraska (1990's), and exhibited significantly higher survival than the remaining 87 families (Table 2). As in the Kansas and South Dakota plantation (Geyer \& Schaefer, 2011), the poorest families were from western provenances. The poorest 10 families had significantly poorer survival than the remaining sources.

\section{Correlation Analysis}

We found no strong relationship between elevation, latitude, or longitude and survival, diameter, height, and $\mathrm{D}^{2} \mathrm{H}$. The $r$ values were significantly different, but very low $(<0.15)$. 
Table 2.

10 best and 10 worst families in the Nebraska ranking of plantation.

\begin{tabular}{|c|c|c|c|c|c|c|c|}
\hline \multicolumn{2}{|c|}{ Survival } & \multicolumn{2}{|c|}{ Diameter } & \multicolumn{2}{|r|}{ Height } & \multicolumn{2}{|c|}{$\mathrm{D}^{2} \mathrm{H}$ volume index } \\
\hline Family $^{1 /}$ & (\%) & Family & cm (in) & Family & $\mathrm{m}(\mathrm{ft})$ & Family & Volume \\
\hline \multicolumn{8}{|c|}{ Top 10 families } \\
\hline 99,001 & $56.7 \mathrm{a}$ & 99,203 & $23.1(9.1 \mathrm{a})$ & 75,704 & 25.5 (7.8a) & 75,704 & 1889a \\
\hline 99,006 & $53.3 \mathrm{~b}$ & 75,704 & $23.1(9.1 \mathrm{a})$ & 75,726 & 25.5 (7.8a) & 99,203 & 1724ab \\
\hline 72,002 & $53.3 \mathrm{~b}$ & 75,703 & 20.1 (7.9ab) & 72,111 & 24.8 (7.6ab) & 72,111 & $1547 a-c$ \\
\hline 72,103 & $53.3 \mathrm{~b}$ & 72,111 & $19.8(7.8 a-c)$ & 72,101 & 24.5 (7.5a-c) & 75,703 & 1457a-d \\
\hline 99,008 & $53.3 \mathrm{~b}$ & 75,735 & $19.8(7.8 \mathrm{a}-\mathrm{d})$ & 75,716 & $24.3(7.4 a-d)$ & 75,726 & 1444a-e \\
\hline 99,003 & $53.3 \mathrm{~b}$ & 75,710 & 19.8 (7.8a-d) & 75,720 & $24.2(7.4 a-d)$ & 75,735 & 1440a-e \\
\hline 99,606 & $47.7 \mathrm{c}$ & 99,103 & 19.6 (7.7a-e) & 75,717 & $24.2(7.4 a-d)$ & 75,710 & 1408a-f \\
\hline 99,404 & $47.7 \mathrm{c}$ & 75,706 & 19.6 (7.7a-e) & 75,724 & $24.4(\mathrm{a}-\mathrm{d})$ & 75,705 & 1404a-f \\
\hline 99,608 & $47.7 \mathrm{c}$ & 72,004 & 19.6 (7.7a-e) & 75,705 & 24.1 (7.3a-d) & 99,611 & 1362b-g \\
\hline 99,405 & $47.7 \mathrm{c}$ & 75,728 & 19.6 (7.7a-e) & 99,611 & 24.1 (7.3a-d) & 99,502 & 1354b-g \\
\hline \multicolumn{8}{|c|}{ Bottom 10 families } \\
\hline 75,209 & $6.6 \mathrm{~h}$ & 99,204 & 16.3 (6.4b-h) & 99,505 & 20.5 (6.2b-g) & 99,201 & $861 f-j$ \\
\hline 99,204 & $6.6 \mathrm{~h}$ & 99,007 & 16.3 (6.3b-h) & 75,730 & 20.5 (6.2b-g) & 99,614 & $850 f-j$ \\
\hline 99,203 & $3.3 \mathrm{~h}$ & 99,101 & $16.3(6.3 \mathrm{c}-\mathrm{h})$ & 99,101 & 20.5 (6.2b-g) & 75,708 & $832 \mathrm{f}-\mathrm{j}$ \\
\hline 75,704 & $3.3 \mathrm{~h}$ & 75,709 & 15.7 (6.2d-h) & 75,709 & 20.2 (6.2b-g) & 99,204 & $818 g-j$ \\
\hline 75,726 & $3.3 \mathrm{~h}$ & 99,614 & 15.7 (6.2d-h) & 99,103 & 20.1 (6.0c-g) & 99,101 & 812g-j \\
\hline 99,502 & $3.3 \mathrm{~h}$ & 72,101 & 15.5 (6.1e-h) & 99,306 & 19.8 (6.0d-g) & 72,106 & $801 g-j$ \\
\hline 75,725 & $3.3 \mathrm{~h}$ & 72,106 & 15.5 (6.1e-h) & 75,708 & 19.8 (6.0d-g) & 75,709 & $780 \mathrm{~g}-\mathrm{j}$ \\
\hline 99,105 & $3.3 \mathrm{~h}$ & 72,105 & 14.7 (5.8f-h) & 99,204 & 19.5 (5.9e-g) & 72,105 & 754h-j \\
\hline 99,502 & $3.3 \mathrm{~h}$ & 99,306 & 14.7 (5.8gh) & 99,303 & 19.2 (5.9f-g) & 99,306 & $656 i-j$ \\
\hline 99,505 & $3.3 \mathrm{~h}$ & 99,505 & $14.2(5.6 \mathrm{~h})$ & 99,201 & $19.0(5.9 \mathrm{~g})$ & 99,505 & $651 \mathrm{j}$ \\
\hline \multicolumn{8}{|c|}{ All sources } \\
\hline $\mathbf{N}$ & 631 & & 631 & & 631 & & 631 \\
\hline Mean & 21.3 & & $17.8(7.0)$ & & $22.4(6.8)$ & & 1126 \\
\hline \multirow[t]{2}{*}{ Sign. } & $<1 \%$ & & $<1 \%$ & & NS & & $<1 \%$ \\
\hline & $3.3-56.7$ & & $14.2-23.1(5.6-9.1)$ & & $19.0-25.5(5.9-7.8)$ & & $651-1126$ \\
\hline
\end{tabular}

${ }^{1 /}$ Note: First 3 numbers of the source code are collection zone and last 2 numbers are tree addition identifiers. Origin 811 was only planted in Kansas.

\section{Summary and Conclusion}

Fast-growing trees are desirable for windbreak establishment in the Great Plains. Ponderosa pine is often planted in homestead and field plantings in the central and northern plains.

Plains-wide studies conducted in the 1960s showed that south-central South Dakota and north-central Nebraska provided better planting materials. The present study was conducted to further refine selection areas for ponderosa pine sources. Materials from 13 collection areas and 76 individual trees were planted at Central Plains sites for evaluation. Within this relatively small area, analyses indicated that geographic origin (provenance) influenced growth of 15-year-old ponderosa pines.

The 5 best collection zones were from the eastern part of
Nebraska (720—Ainsworth; 721—Valentine; 990—Spring view; 994-Bassett; and 996-Sparks). The poorest collection zoneswere found in the western areas. Growth of the top 10 individual tree families came from both Nebraska and South Dakota. Seventy percent grew well.

\section{REFERENCES}

Baer, N. W., \& Collins, P. E. (1979). Ten-year performance of a ponderosa pine provenance study in eastern South Dakota. South Dakota State University Agricultural Experiment Station, Brookings, TB-52, $6 \mathrm{p}$

Critchfield, W. B., \& Little, E. L. Jr. (1966). Geographic distribution of the pines of the world. Washington, DC: USDA, Miscellaneous Publication 991, 97p. 
Flint, H. L. (1983). Landscape plants for eastern North America. John Wiley \& Sons, New York, 677 p.

Deneke, J. J., \& Read, R. A. (1975). Early survival and growth of ponderosa pine provenances in East-Central Kansas. USDA Forest Service Research Note RM-297, Rocky Mountain Experiment Station, Ft. Collins, 4p.

Geyer, W. A. (2011). Evaluation of ponderosa pine seed sources for windbreaks in the Central Great Plains of the United States. Arboriculture \& Urban Forestry, 37, 265-268.

Lambeth, C. (1980). Juvenile-mature correlations in Pineaceae and implications or early selection. Forest Science, 26, 571-580.

Koop, R. F., Geyer, W. A., Argent, R. M., \& Lynch, K. D. (1987). Evaluation of ponderosa seed sources for the eastern Great Plains. Journal Arboriculture, 13, 139-144.

Read, R. (1983). Ten-year performance of ponderosa pine provenances in the Great Plains of North America. USDA Forest Service Research Paper,Rocky Mountain Experiment Station, Ft. Collins, 17p.

SAS Institute Inc. (2002-2003). SAS/STAT user's guide (Version 9.1). Cary, NC: SAS Institute Inc.

Schaefer, P. R., \& Baer, N. W. (1985). Ponderosa pine provenance for windbreaks in eastern South Dakota. Northern Journal of Forestry, 2, 105-107.

Schaefer, P. R., \& Baer, N. W. (1992). Stability of ponderosa pine provenance: results after 21 years in eastern South Dakota. Northern Journal of Forestry, 9, 102-107.

Van Haverbeke, D. F. (1986). Genetic variation in ponderosa pine: A 15-year test of provenances in the Great Plains. USDA Forest Service Rocky Mountain Forest Range Experiment Station Research Paper 80526, 16 p. 